\title{
MOVING FORWARD TOGETHER
}

THE 30-YEAR PARTNERSHIP OF MONGOLIA AND THE ASIAN DEVELOPMENT BANK

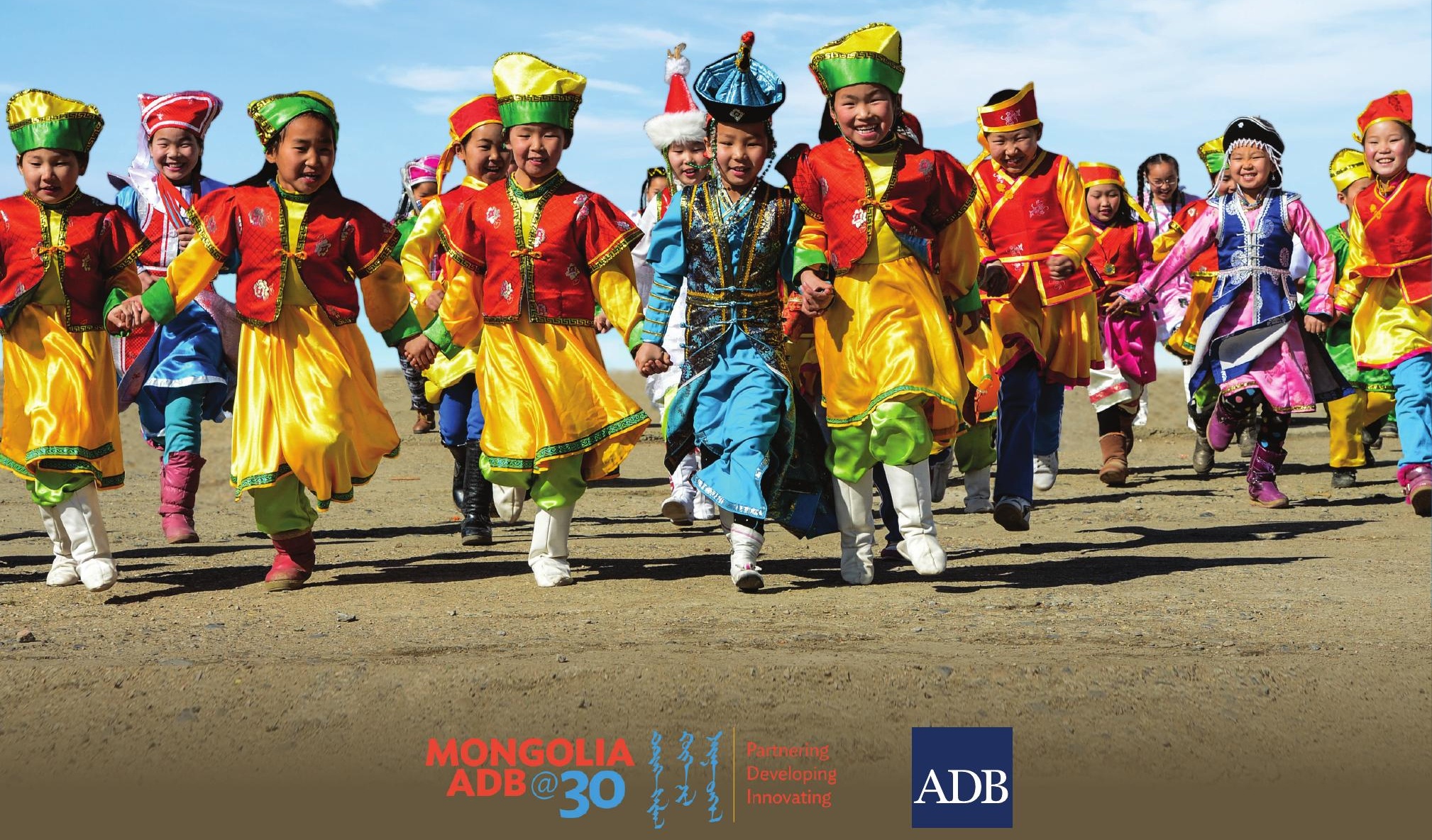




\section{MOVING FORWARD TOGETHER}

THE 30-YEAR PARTNERSHIP OF MONGOLIA AND THE ASIAN DEVELOPMENT BANK 
(C) 2021 Asian Development Bank

6 ADB Avenue, Mandaluyong City, 1550 Metro Manila, Philippines

Tel +632 8632 4444; Fax +63286362444

www.adb.org

Some rights reserved. Published in 2021

ISBN 978-92-9269-132-5 (print); 978-92-9269-133-2 (electronic); 978-92-9269-134-9 (ebook)

Publication Stock Number: ARM210427-2

DOI: http://dx.doi.org/10.22617/ARM210427-2

The views expressed in this publication are those of the authors and do not necessarily reflect the views and policies of the Asian Development Bank (ADB) or its Board of Governors or the governments they represent.

ADB does not guarantee the accuracy of the data included in this publication and accepts no responsibility for any consequence of their use. The mention of specific companies or products of manufacturers does not imply that they are endorsed or recommended by ADB in preference to others of a similar nature that are not mentioned.

By making any designation of or reference to a particular territory or geographic area, or by using the term "country" in this document, ADB does not intend to make any judgments as to the legal or other status of any territory or area.

This work is available under the Creative Commons Attribution 3.0 IGO license (CC BY 3.0 IGO)

https://creativecommons.org/licenses/by/3.0/igo/. By using the content of this publication, you agree to be bound by the terms of this license. For attribution, translations, adaptations, and permissions, please read the provisions and terms of use at https://www.adb.org/terms-use\#openaccess.

This CC license does not apply to non-ADB copyright materials in this publication. If the material is attributed to another source, please contact the copyright owner or publisher of that source for permission to reproduce it. ADB cannot be held liable for any claims that arise as a result of your use of the material.

Please contact pubsmarketing@adb.org if you have questions or comments with respect to content, or if you wish to obtain copyright permission for your intended use that does not fall within these terms, or for permission to use the ADB logo.

Corrigenda to ADB publications may be found at http://www.adb.org/publications/corrigenda.

Notes:

In this publication, “\$” refers to United States dollars.

ADB recognizes "Korea" as the Republic of Korea.

Photos in this publication are taken from the ADB Photo Library unless otherwise stated.

On the cover: Schoolchildren in Binder soum, Khentii aimag, Mongolia (photo by Chadraabal Baramsai). 


\section{CONTENTS}

FOREWORD BY THE GOVERNMENT OF MONGOLIA V

FOREWORD BY THE ASIAN DEVELOPMENT BANK vi

ACKNOWLEDGMENTS $\quad x$

GLOSSARY

ABBREVIATIONS

CURRENCY EQUIVALENTS $\quad$ xi

CHAPTERS AND SECTORS - A READER'S QUICK GUIDE Xii

ADB ASSISTANCE TO MONGOLIA

CHAPTER 1. A TESTING TIME: COVID-19 AND BEYOND 2

CHAPTER 2. A NEW ERA: 1991-2000

Country at a Glance $\quad 5$

Shifting to a New Economic System — Personal Views 10

Rehabilitation and Overcoming Isolation: ADB Operations 18

Civil Aviation - Flying High 19

Telecommunications - Making New Connections $\quad 20$

Energy - Building Stability and Security 23

$\begin{array}{ll}\text { CHAPTER 3. A PATH TO RECOVERY: 2001-2010 } & 28\end{array}$

Country at a Glance $\quad 28$

Emerging from Transition: ADB Operations $\quad 32$

Finance - Banking on the Future $\quad 34$

$\begin{array}{ll}\text { Education - Setting the Foundation } & 37\end{array}$

Health — Providing Grassroots Services $\quad 45$

Social Protection - Supporting the Vulnerable $\quad 49$

Urban Development - Meeting Basic Needs 
CHAPTER 4. A DYNAMIC TRANSFORMATION: 2011-2020

Country at a Glance $\quad 62$

Tackling New Challenges: ADB Operations $\quad 64$

$\begin{array}{ll}\text { Transport — Linking Communities and Countries } & 67\end{array}$

Trade Facilitation — Removing Barriers, Improving Safety 70

Agriculture - Growing Green Gold $\quad 74$

Natural Resources - Protecting the Future $\quad 93$

Private Sector - Enabling Business $\quad 86$

CHAPTER 5. FUTURE COOPERATION

Looking Back, Moving Forward

$\begin{array}{ll}\text { Challenges } & 94\end{array}$

Partnering with ADB 96

Messages from Country Directors $\quad 98$

$\begin{array}{ll}\text { Barry Hitchcock } & 98\end{array}$

$\begin{array}{ll}\text { Adrian Ruthenberg } & 99\end{array}$

$\begin{array}{ll}\text { Robert Schoellhammer } & 100\end{array}$

Yolanda Fernandez Lommen 101

$\begin{array}{ll}\text { Pavit Ramachandran } & 106\end{array}$ 


\section{FOREWORD BY THE GOVERNMENT OF MONGOLIA}

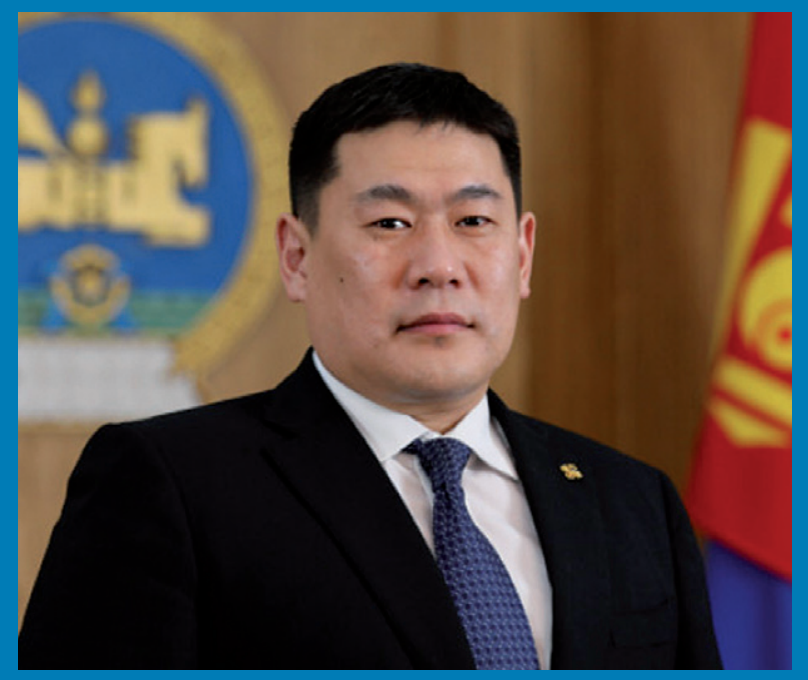

Mongolia and the Asian Development Bank (ADB) have reached an important milestone of three decades of partnership. As the Prime Minister of Mongolia, I would like to extend my congratulations to and appreciation for ADB for your steadfast support for our country's historic development journey.

On this celebrated day of 30th anniversary, we are diligently reviewing our track record of cooperation and defining our common goal of creating inclusive and sustainable development for Mongolia in the future.

Since Mongolia joined ADB as a member country in 1991, we have shared a proud partnership addressing vital development areas, including our work to ensure economic stability, reduce poverty, develop education, health, and infrastructure, and support green growth.

Although the 30 year long development path of Mongolia has had its complications, ADB has been a reliable and constant partner supporting our country through economic cycles, global financial and economic crisis, natural disasters, and challenges arising from the Coronavirus (COVID-19) pandemic.

At a time when humanity is in its second year of overcoming a global pandemic that has shaken the world like it has not experienced since World War II, it is of great importance and timely that ADB is launching its new partnership strategy with the Government of Mongolia.

I am certain that this new partnership strategy that aligns with "Vision 2050", Mongolia's long-term development policy approved by the Parliament, will support the successful implementation of the new economic recovery policy, which aims to overcome the negative impacts of the COVID-19 pandemic, revive the economy and support the middle class.

May our partnership united under a common vision towards humanity's aspirations and regional development be successful and impactful.

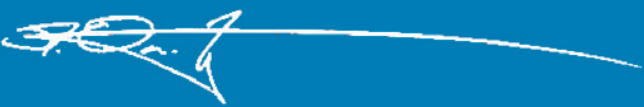

Oyun-Erdene Luvsannamsrai

Prime Minister

Government of Mongolia 


\section{FOREWORD BY THE ASIAN DEVELOPMENT BANK}

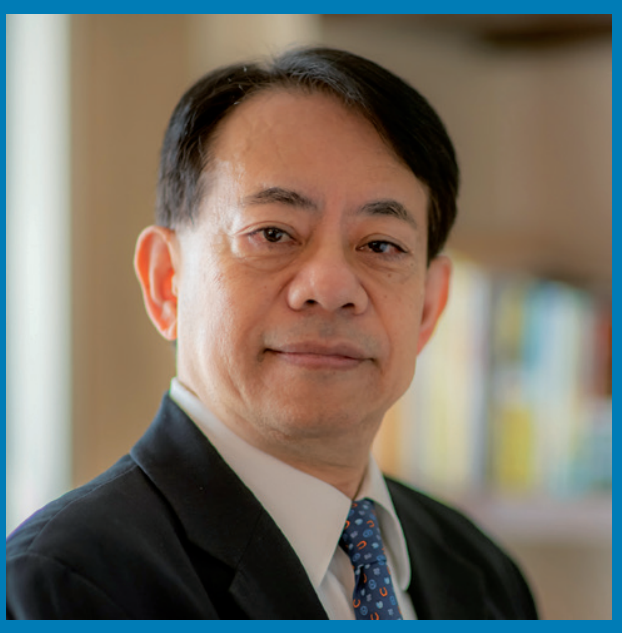

Mongolia, with a long and storied history, is a vast, landlocked country located between the People's Republic of China and the Russian Federation.

Rich in natural resources, Mongolia occupies an area almost half the size of India; yet, it is one of the most sparsely populated countries in the world with just 3.3 million people, of which close to half live in the capital, Ulaanbaatar. Climate extremes, with harsh winters and searing summer temperatures in the Gobi Desert, have helped shape Mongolia's proud nomadic herding tradition and produced hardy and resourceful people.

After decades of dependence on the Soviet Union, Mongolia began a major economic and political transition during the 1990s. The withdrawal of aid from the Soviet Union left the country in increasingly deep economic distress, spurring Mongolia to reach out to development partners, including the Asian Development Bank (ADB), for assistance.

Mongolia joined ADB in 1991. The country worked with ADB and other partners to stabilize finances, carry out sweeping governance and banking reforms, and rehabilitate ageing infrastructure. Mongolia adopted a parliamentary democracy, with a free press and civil liberties protected by a constitution that was enacted in 1992.

Over the past 30 years, ADB has become Mongolia's largest multilateral development partner, supporting its transformation into a market-based economy with projects, programs, and technical assistance across multiple sectors, including agriculture, education, energy, finance, health, transport, and urban development.

Over the course of the partnership, Mongolia has seen substantial economic and social gains. Gross domestic product (GDP) per capita has increased almost three-fold since 2000 in real terms, maternal and infant mortality rates are down sharply since the country's transition began, access to safe water and sanitation have risen substantially, and adult literacy and primary school enrollment rates are close to $100 \%$. The private sector now dominates the economy, accounting for about $80 \%$ of GDP and providing over $75 \%$ of employment.

There have been, of course, many challenges along the way. The economy was badly affected by the regional and global financial crises around 1998 and in 2008, while huge livestock losses during a number of brutal winter dzuds left many nomadic herders without livelihoods, forcing them to 
migrate to urban centers where many live in ger areas with few services. An over-reliance on income from mining, which accounts for $90 \%$ of exports, has seen government revenues whipsawed by sharp fluctuations in commodity prices.

The onset of the coronavirus disease (COVID-19) pandemic in 2020 is providing another stern test, reversing years of growth gains, slowing reforms, increasing unemployment, and highlighting challenges in the country's health and social protection systems.

ADB has been helping Mongolia tackle the immediate fallout from the pandemic with funding for medical equipment and vaccines, support for social protection, and assistance to private businesses essential to the nation's economic recovery. For the longer term, it is also financing reforms that will better prepare Mongolia to manage future health crises.

In over three decades, Mongolia has undergone a rapid and significant transformation. Now, as it looks to the future, it will need to address remaining constraints that are holding back the creation of a more resilient and broad-based economy.

These constraints include a lack of economic diversity, infrastructure gaps, inefficiencies in agriculture, pressures on services and the environment in both urban and rural areas, a workforce lacking digital skills, and inequalities that prevent marginalized groups from full participation in the economy.

ADB's new country partnership strategy for 2021-2024, which is closely aligned with Mongolia's policy priorities in Vision 2050 and the Government Action Plan 2020-2024, provides a blueprint to help tackle these challenges, including the ongoing COVID-19 pandemic. It will support Mongolia through three core pillars: (i) with assistance for health, education, skills development, and social protection; (ii) further infrastructure upgrades to drive economic competitiveness and diversification; and (iii) support for more sustainable and green development to reduce environmental degradation and to manage the impacts of climate change. It will also focus on hastening Mongolia's shift to a digitalbased economy, and support entrepreneurship by providing assistance for innovative business ideas and start-up companies.

Helping women play a full role in the formal economy is another important goal. An ADB study in Mongolia has shown that if women had the same labor participation rate as men, this could boost economic growth by as much as 0.5 percentage points every year.

ADB looks forward to continuing its close relationship with Mongolia and supporting this dynamic nation's drive to meet its development goals and fully transform into a vibrant, modern economy with a thriving middle class by 2050 .

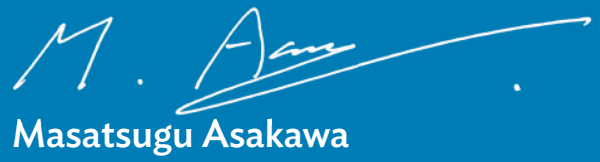

President of the Asian Development Bank 
Summertime. Animals graze in the valleys of Arkhangai aimag during the Mongolian summer (photo by Oktyabri Dash).

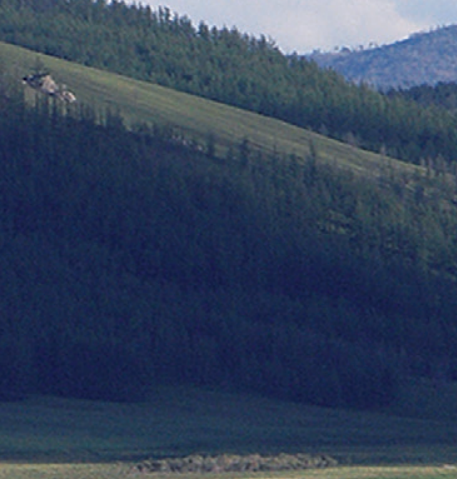

$\sin$
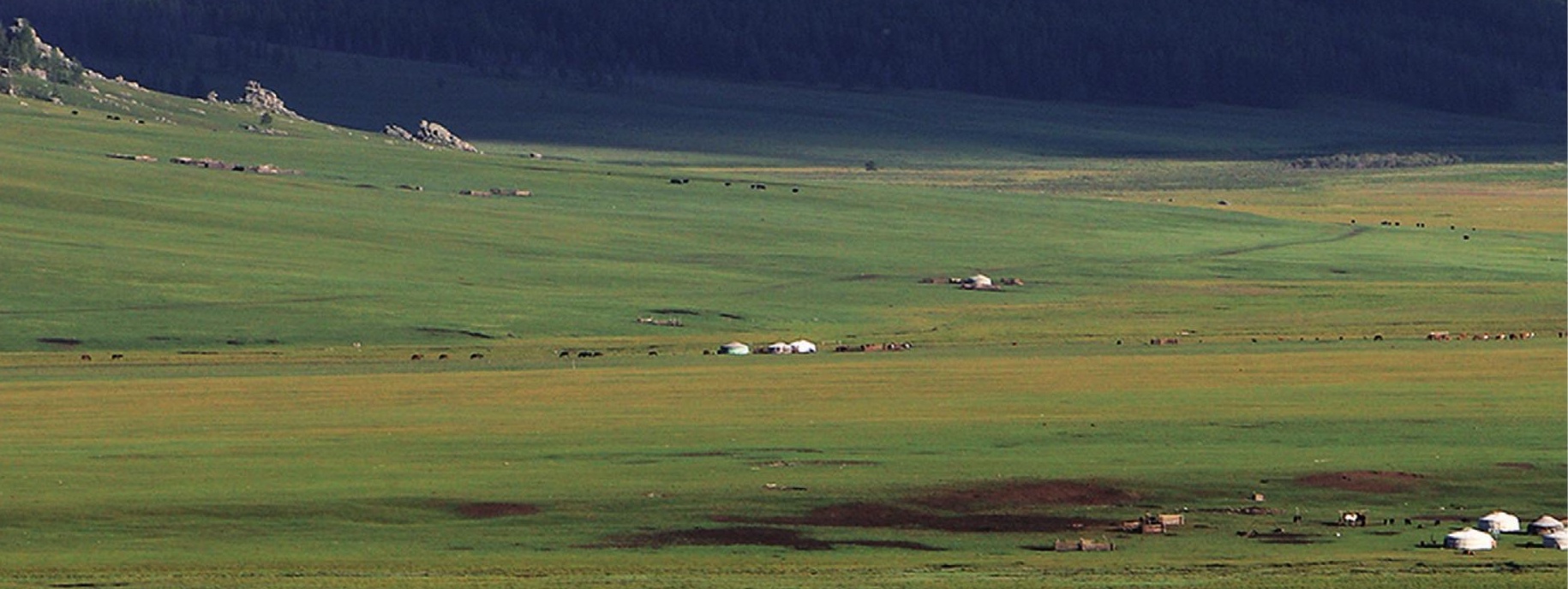

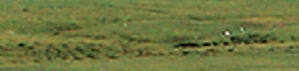

What of

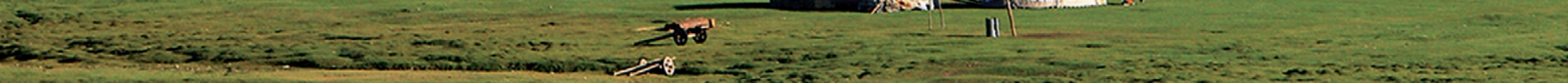

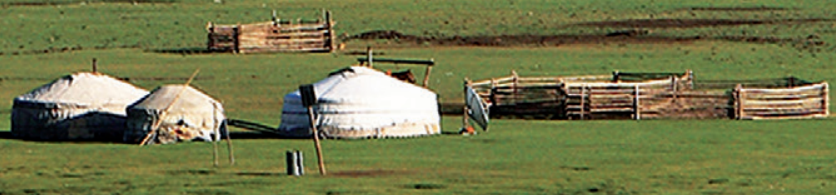

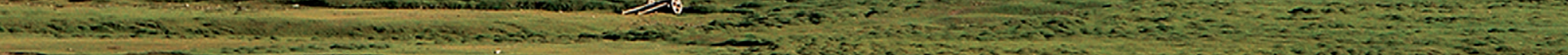

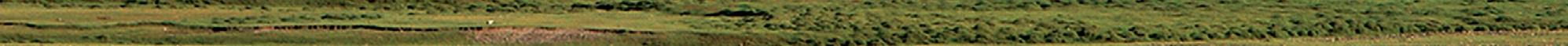
W

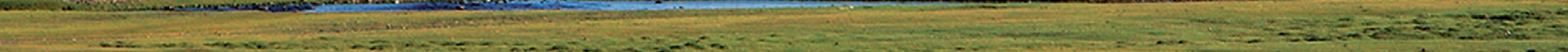

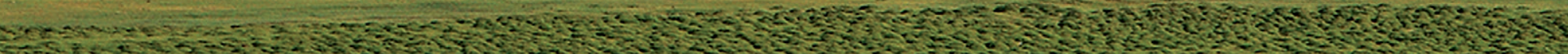

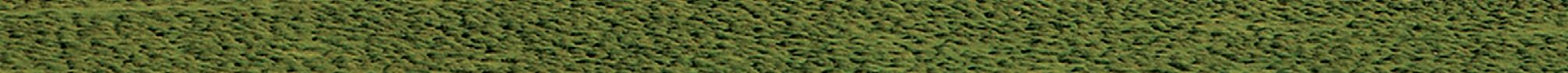

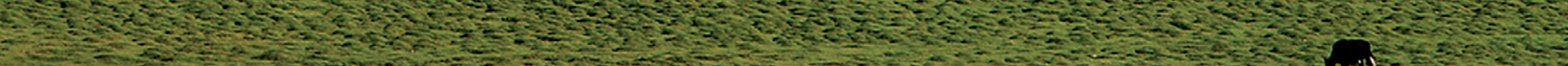
-

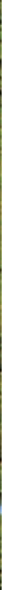




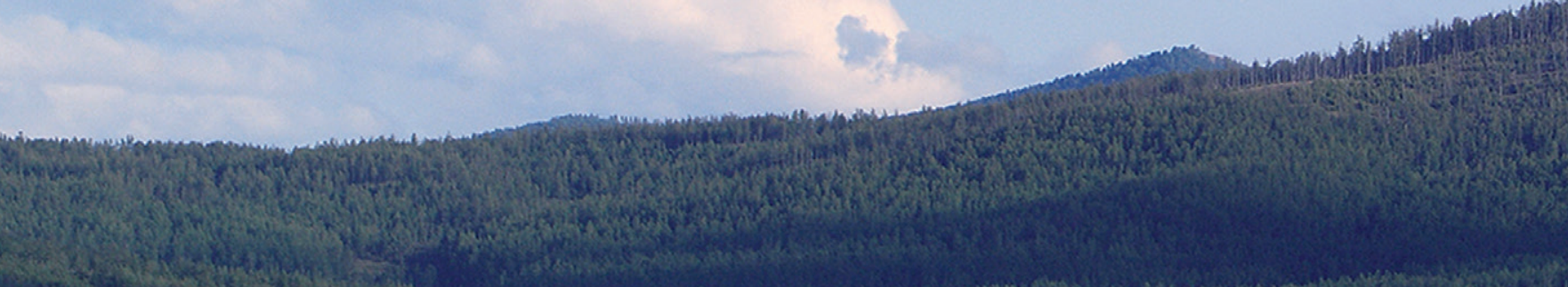

$$
\begin{aligned}
& 20 \\
& \text { 파라: } \\
& \text { anctist } \\
& \text { - }
\end{aligned}
$$

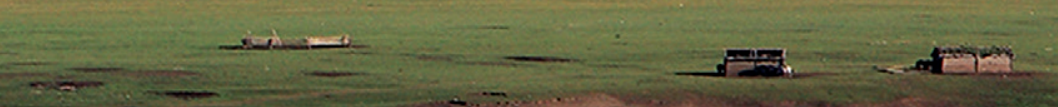

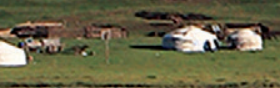

ath abros.

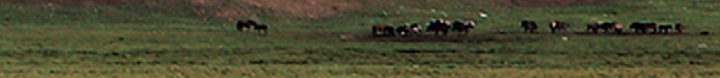

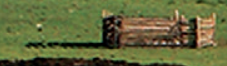

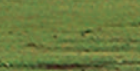

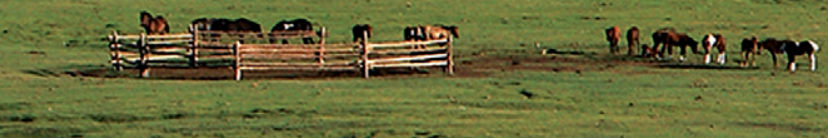

(D)

$-200000=$

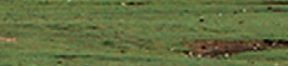

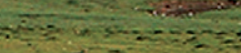

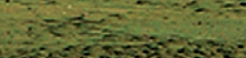

Sul-

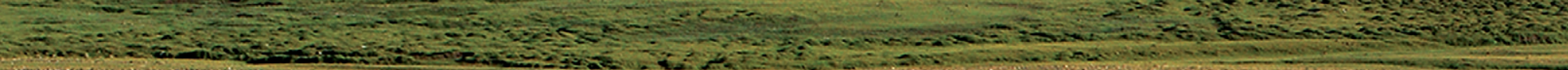

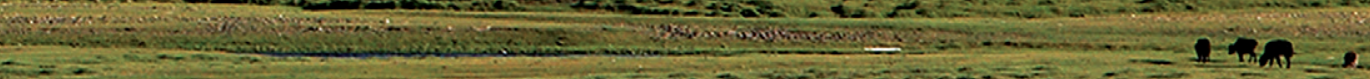

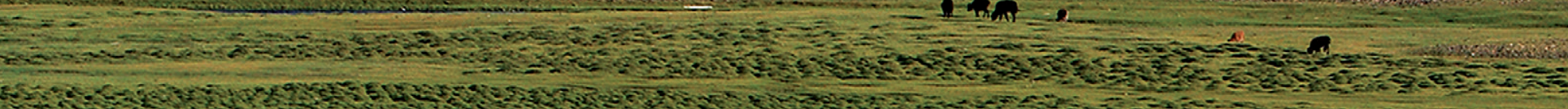

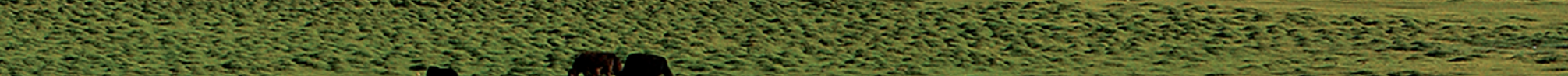

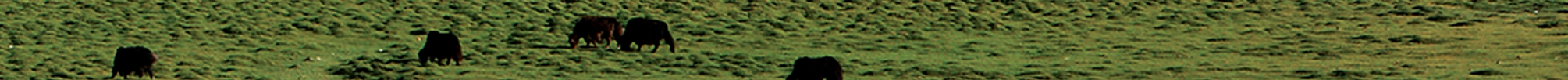

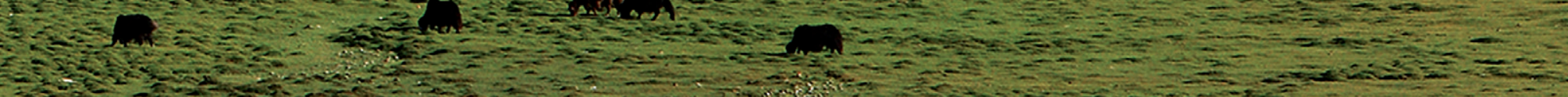

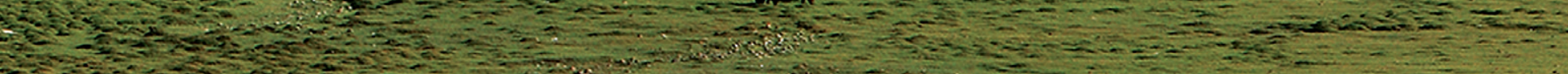

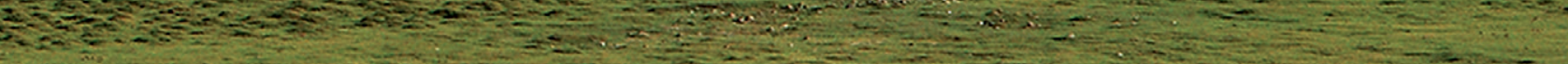

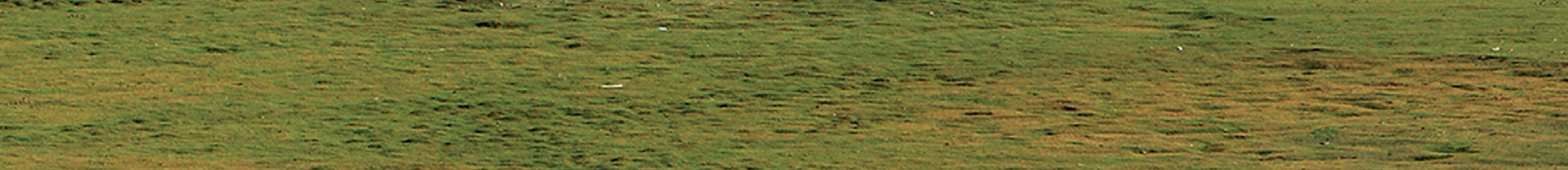

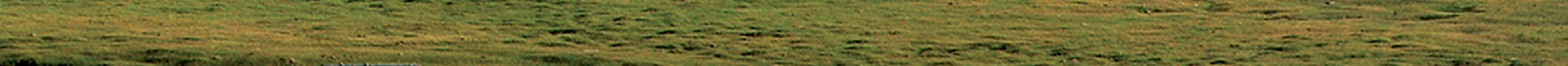
Lan

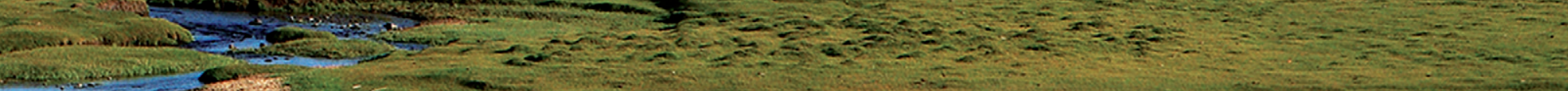




\section{ACKNOWLEDGMENTS}

This publication was prepared by the Asian Development Bank (ADB) under a technical assistance project, TA 6622-MON: Deepening ADB-Mongolia Partnership for its 30th Anniversary, with overall guidance and supervision provided by Pavit Ramachandran, ADB's country director, Mongolia Resident Mission (MNRM); and Gantuya Ganzorig, senior external relations officer, MNRM.

The publication was authored by national content writing expert Munkh-Orgil Zorig and international content writing expert Michael Barker.

Peer review of the manuscript and generous research support was provided by the ADB MNRM staff, Tuul Badarch, Batjargal Battsengel, Shannon Christine Cowlin, Unurjargal Dalaikhuu, Enerelt Enkhbold, Anand Ganbaatar, Arnaud Heckmann, Altantuya Jigjidsuren, Itgel Lonjid, Declan Magee, Ongonsar Purev, Bold Sandagdorj, and Oyunchimeg Suren. The manuscript was reviewed by Xiaoqin Fan, director of Public Management, Financial Sector and Regional Cooperation Division; Sujata Gupta, director of Sustainable Infrastructure Division; Thomas Panella, director of Environment, Natural Resources, and Agriculture Division; and Sangay Penjor, director of Urban and Social Sectors Division of ADB's East Asia Department.

Valuable inputs have been received from Ochirbat Punsalmaa, former President of Mongolia, and Molomjamts Demchigjav, former Governor of the Bank of Mongolia and ADB Governor for Mongolia. Contributions from former ADB country directors to Mongolia and other stakeholders, including project staff, have been instrumental in telling the story of Mongolia and ADB's 30 years of partnership. The concluding chapter of the publication has benefited from the assessment and vision of $M$. Teresa Kho, director general of ADB's East Asia Department.

We would also like to specially acknowledge the photographic contributions of our former colleague and dear friend Mookiah Thiruchelvam who is, sadly, no longer with us. 


\section{GLOSSARY}

$\begin{array}{lll}\text { aimag } & - & \begin{array}{l}\text { primary administrative unit (equivalent to } \\ \text { province) of Mongolia }\end{array} \\ \text { dzud } & - & \begin{array}{l}\text { extreme weather conditions caused by heavy, } \\ \text { long-lasting or frequent snowfall, extreme cold, } \\ \text { or storms that often cause massive livestock } \\ \text { losses }\end{array} \\ \text { ger } & - & \begin{array}{l}\text { traditional Mongolian dwelling (or tent) made } \\ \text { of wood frame and felt covers, widely used by } \\ \text { nomadic herders }\end{array} \\ \text { soum } & - & \text { administrative subunit of an aimag }\end{array}$

\section{ABBREVIATIONS}

$\begin{array}{ll}\text { ADB } & - \text { Asian Development Bank } \\ \text { COVID-19 } & - \text { coronavirus disease } \\ \text { GDP } & - \text { gross domestic product } \\ \text { IMF } & - \text { International Monetary Fund } \\ \text { LLC } & - \text { Limited Liability Company } \\ \text { MSMEs } & - \text { micro, small, and medium-sized enterprises } \\ \text { PRC } & - \text { People's Republic of China }\end{array}$

\section{CURRENCY EQUIVALENTS}

(as of 5 October 2021)

$\begin{array}{ll}\text { Currency unit } & -\operatorname{togrog}(\mathrm{MNT}) \\ \text { MNT1.00 } & =\$ 0.00035 \\ \$ 1.00 & =\text { MNT2,850.02 }\end{array}$




\section{CHAPTERS AND SECTORS A READER'S QUICK GUIDE}

The publication includes chapter 1 outlining the operations of the Asian Development Bank (ADB) in response to COVID-19 (2020-2021), and chapters 2-4 covering ADB's operations over three decades (1991-2000; 2001-2010; 2011-2020).

Chapters 2-4 have been arranged to highlight sectors where ADB has played a prominent role in supporting Mongolia's transformation and development in each of the three decades.

While most of the programs, projects, and technical assistance activities in each decade chapter were implemented during the 10-year period they are included in, some were carried out in earlier or later periods.

The decision to present the material in this way was to help readers get a full and complete understanding of operations in each sector across the full partnership period without having to switch back and forth across different decades and chapters. 


\section{ADB ASSISTANCE TO MONGOLIA}

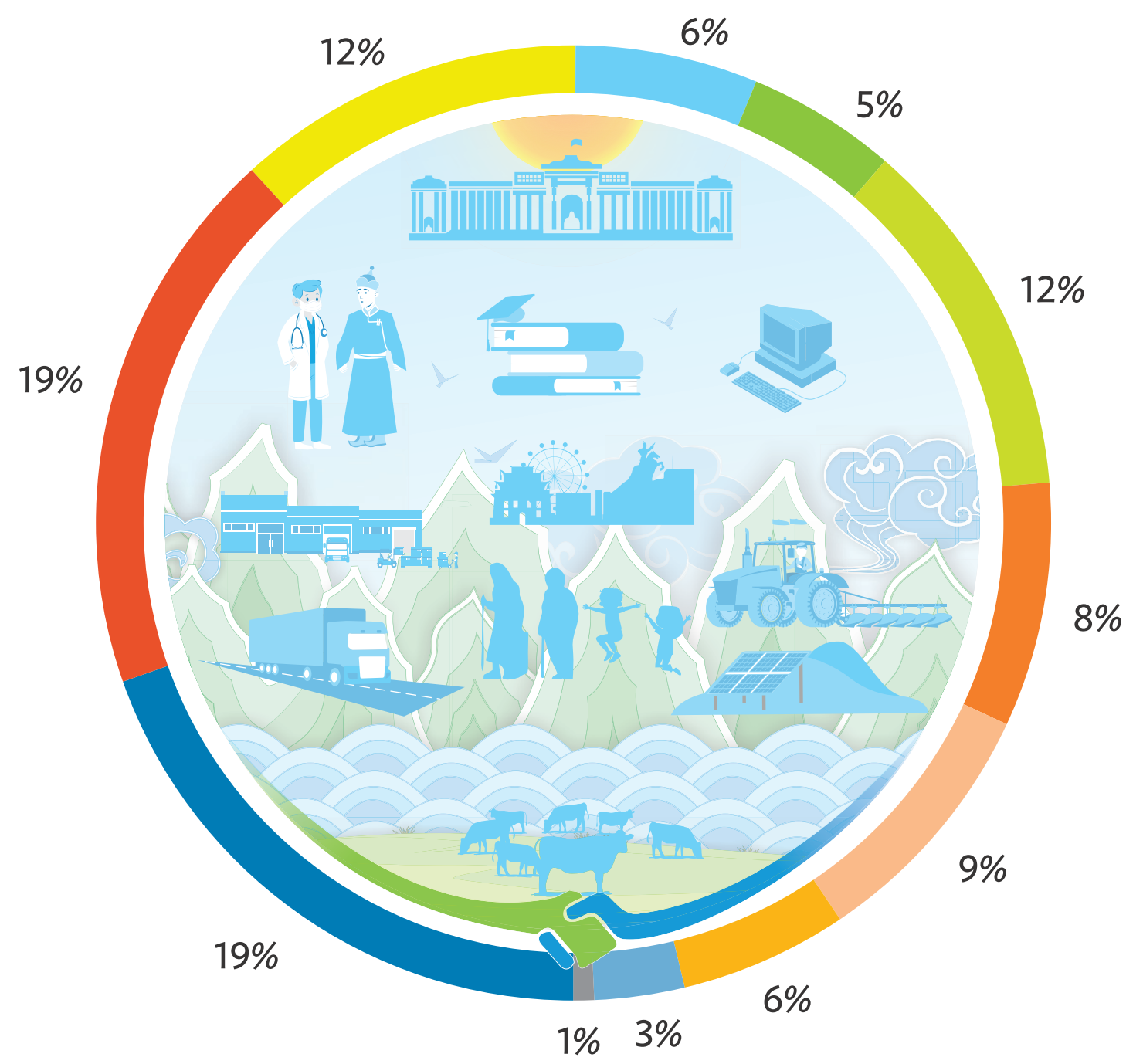

Cumulative Sovereign Loans, Grants, and Technical Assistance Commitments (1991-2020)

Agriculture, Natural Resources and Rural Development

\section{Education}

Energy

Finance
Health and Social Protection

Industry and Trade

Information and

Communications Technology

Multisector
Public Sector Management

Transport

Water and Other Urban

Infrastructure and Services

Note: Percentages per sector correspond to ADB assistance commitments totaling $\$ 3.6$ billion. Source: Asian Devevelopment Bank. 


\section{CHAPTER 1}

\section{A TESTING TIME: COVID-19 AND BEYOND}

When the coronavirus disease (COVID-19) began spreading rapidly around the world in early 2020, the Government of Mongolia moved swiftly to respond. It introduced border closures, suspended air travel, and imposed strict quarantine rules.

While this greatly reduced the human toll from the virus, there were deep and immediate impacts on the economy, which, in 2020, plunged into a major contraction for the first time in 11 years.

Job losses spiked, companies struggled with weakening demand and difficulties in accessing capital, and households saw reduced incomes alongside higher food prices. Incidences of domestic violence rose, linked to long periods of lockdown and rising unemployment.

To help alleviate the harsh impacts of the virus, particularly on vulnerable groups, the government announced a $\$ 1.8$ billion Countercyclical Development Expenditure Plan in March 2020 to increase financing for the health sector, social protection, and for supporting households through tax relief measures.

The Bank of Mongolia introduced several policy measures to ease pressures on banks and to support small and medium-sized enterprises.

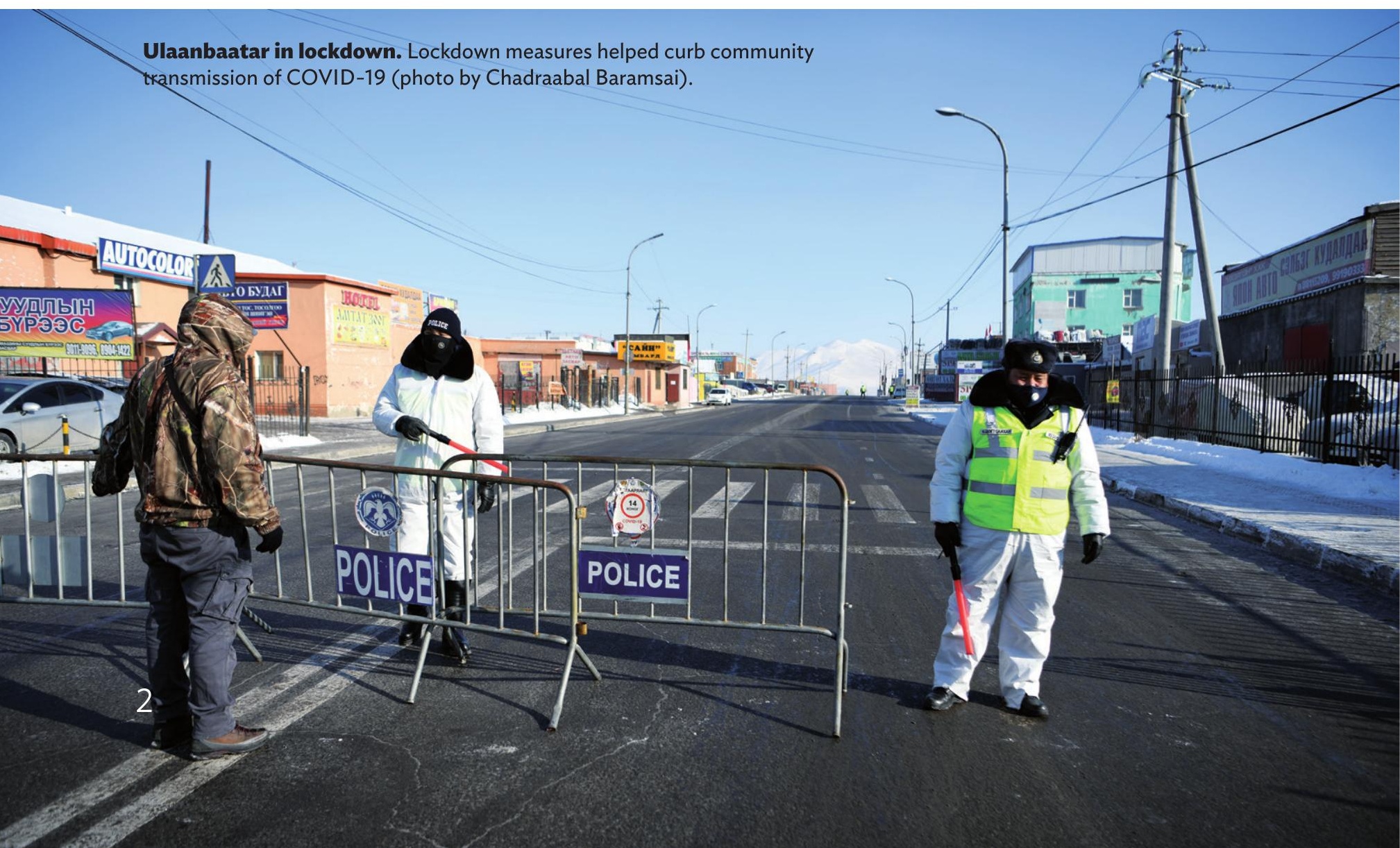


In February 2021, the Government of Mongolia announced a $\$ 3.5$ billion 3-year Comprehensive Plan for Health, Security, and Economic Recovery to help revitalize the economy.

The Asian Development Bank (ADB) was among the first of the multilateral agencies to come to Mongolia's aid in 2020. Assistance was extended from as early as February for personal protective equipment for customs, inspection, and emergency service officials, along with the repurposing of an existing loan to fund medical equipment for the diagnosis and treatment of patients with respiratory problems in all aimag, district, and referral-level hospitals. Technical assistance was provided to establish an Incident Management System that is helping Mongolia respond quickly to COVID-19 infections and build up its overall capacity for infection prevention and control.

These initial measures were followed by a $\$ 100$ million loan, delivered in a little over 4 weeks, to support the government's countercyclical plan. Additional loans totaling $\$ 99.4$ million were provided for food and child-targeted income support to needy households, and to strengthen social welfare programs. Over $\$ 32$ million was committed for laboratories to diagnose COVID-19 and for additional hospital equipment for critically ill patients in public hospitals.

Liquidity assistance was extended for two of the country's leading food-related companies to maintain their operations and preserve the livelihoods of thousands of farmers, workers, and sales agents.
To help the government meet its goal of vaccinating $65 \%$ of its population by the end of 2021, ADB has committed $\$ 19$ million, through its Asia Pacific Vaccine Access Facility, to purchase vaccines for priority groups, including about 200,000 frontline workers.

Looking to the future, ADB approved another $\$ 100$ million loan in March 2021 to support further sector reforms needed to help Mongolia exit the pandemic and to make the health system more resilient and better able to withstand future shocks. That includes measures to better regulate medicines and pharmacies, strengthen governance for public hospitals, and establish a single purchaser for health services.

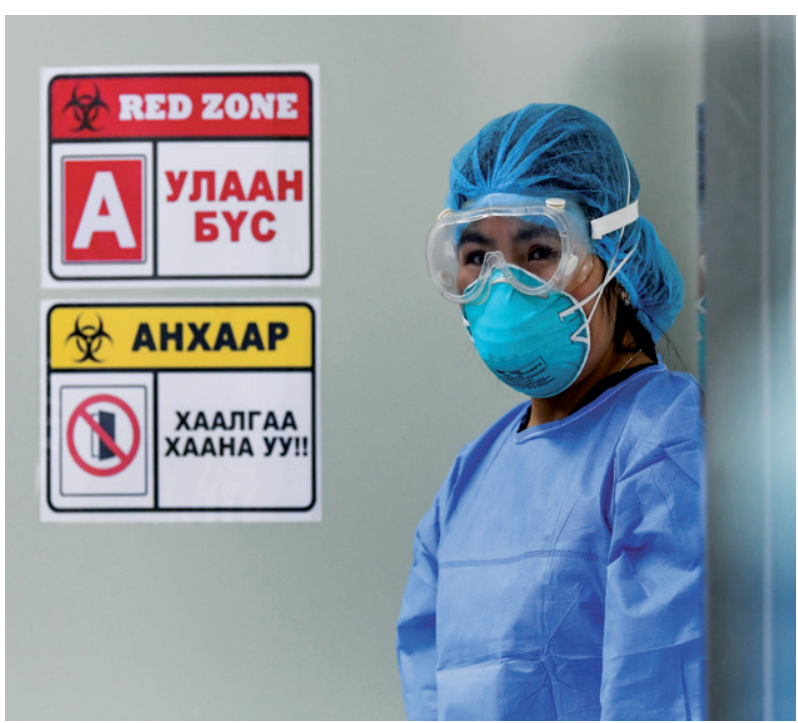

Red zone. Health care and emergency professionals work tirelessly to save lives during the pandemic (photo by Chadraabal Baramsai). 
ADB's strong and close relationship with the government, forged over 3 decades, helped speed the process of identifying areas for assistance and for committing funds.

While responses have been swift and effective, the pandemic has been a sobering experience for Mongolia, undoing economic and development gains, exposing limitations in its health and social protection systems, and accentuating societal inequalities, particularly those experienced by women who play a dominant role in the health sector and in small business.
The country's continued heavy dependence on mining, which accounts for almost a quarter of gross domestic product (GDP) and as much as $90 \%$ of exports in some years, was again brought into sharp focus as demand from the People's Republic of China fell and commodity prices slumped. ${ }^{1}$

Working closely with the government, ADB has now finalized a new country partnership strategy for Mongolia, 2021-2024 that aims to address these challenges.

${ }^{1}$ ADB. 2020. Mongolia's Economic Prospects: Resource-Rich and Landlocked between Two Giants. Manila. p.73

Last snow of the long winter. The central square of Ulaanbaatar in late March 2021 (photo by Mookiah Thiruchelvam). 